\title{
Malaysia's Leadership Role in Asean: An Assessment
}

\author{
${ }^{1}$ Siti Darwinda Mohamed Pero \& Laila Suriya Ahmad Apandi \\ School of International Studies \\ Universiti Utara Malaysia, Malaysia \\ ${ }^{1}$ Corresponding author: darwinda@uum.edu.my \\ DOI: https://doi.org/10.32890/jis2018.14.5
}

Received: 5 June 2018

Revised: 11 August 2018

Accepted: 30 December 2018

\begin{abstract}
There has been perpetual controversy regarding the leadership of ASEAN, that is complicated and hitherto been a cause for concern. The largest and most populated country in Southeast Asia is Indonesia, and has been regarded as the de facto leader in ASEAN for its influence to spur progress within the organization. However, this does not undermine the role of the other four founding members of ASEAN, specifically Singapore, Thailand, Philippines and Malaysia. Singapore has been considered the leader of ASEAN in the economic realm, championing and pushing forward economic agendas of the organization and its member-states. Moreover, the Philippines have been a strong advocate in promoting and enhancing the socio-cultural development within the organization. Conversely, the role of Malaysia in ASEAN has been scholarly neglected. This study seeks to fill the gaps by analysing the role of Malaysia in ASEAN since 1967, and propose that Malaysia has had a significant degree of influence within the organisation. By incorporating document analysis, this study presents the findings on Malaysia's pivotal role in ASEAN. The results conclude that Malaysia was and is still a key leader in the organization and the country should continue to exercise its prerogative for the benefit of its national interest, in addition to maintaining peace, stability and prosperity in the region.
\end{abstract}

Keywords: Leadership, Malaysia, ASEAN, Foreign policy, Regional organisation, Southeast Asia.

\section{Introduction}

Malaysia has been an active member of the Association of Southeast Asian Nations (ASEAN) since its establishment on 8 August 1969. ASEAN has been the cornerstone for Malaysia's foreign policy whereby the country has been regarded as a prosperous trading nation with a multicultural demography (Ministry of Foreign Affairs, 2019). As a member of ASEAN, Malaysia has played a pivotal role in facilitating and shaping the overall progress and development of ASEAN over the five decades since its inception. Various programmes and incentives have been proposed, launched and executed by Malaysia at the ASEAN level, as evidence of their participation in the organisation. 
Nevertheless, numerous scholarly works on ASEAN and its member-states in chartering its progress within the organisation has been focused on roles played by Indonesia and Singapore (Emmers, 2014; Rattanasevee, 2014), and to some extent, the Philippines (Severino, 2006). Indonesia has been regarded as the de facto leader of ASEAN since its foundation in 1967 (Anwar, 1997). Indonesia, under the leadership of Suharto from 1966 to 1998, has been able to exert its influence in determining ASEAN's policies as well as the overall progress of the organization. Singapore has been considered an influential memberstate in ASEAN that champions the agendas and policies on economy and trade (Severino, 2006). Conversely, the Philippines has been advocating multiple socio-cultural agendas in ASEAN's community-building efforts.

Malaysia's role(s) in ASEAN has received little attention from scholars. This study seeks to fill the gap by analysing Malaysia's role in ASEAN since 1967. The study adopts the case study design, which involves 'a research strategy that focuses on understanding the dynamics present within a single setting (s) (Eisenhardt 1989, p. 534). Essentially, the study utilises a multiple case study design to examine the entire process of ASEAN's communitybuilding efforts, from its establishment to its current state of progress. This examination includes an assessment on political leaderships' role in the establishment of ASEAN. These case studies deal with historical events, including an analysis on the decisions, responses and behaviour of ASEAN leaders in tackling current challenges such as the South China Sea territorial and maritime disputes. Multiple case study analysis offer a distinct advantage as they are often considered 'more compelling, and the conclusions more robust' (Klenke 2008, p. 65).

Based on data collected by analysing documents from primary and secondary sources, this study is aimed at presenting a detailed and compelling case for Malaysia's significant role in chartering the progress of ASEAN. The study utilises a range of data, from speeches and statements concerning ASEAN, official reports, publications, and archival records on ASEAN agreements and ratification. In addition, secondary sources such as newspapers and journals related to Southeast Asia were also analysed. Media reports were useful in complementing information gathered from primary documents as well as for obtaining insights into more urgent decision-making processes at any given time. Online news reports were accessed via the LexisNexis and Factiva databases.

Understanding the degree to which Malaysia has been able to exert its influence on ASEAN has been of great importance to policy-makers, academicians and practitioners due to the significant political influence Malaysia has within its country. Dr Mahathir Mohamad was the 4th Prime Minister before being reelected as the 7th Prime Minister of Malaysia in the recent general election in 2018. Hence, it is anticipated that with the presence of Dr Mahathir Mohamad, Malaysia will continue to play an active and paramount role in ASEAN, that was previously effective during the 1990s and early 2000s. 


\section{Leadership in the Regional Organisation}

There are various definitions of leadership. The term has been used in various fields including domestic and international politics, corporate management and education (Young, 1991, p.281). In general, leadership is defined as the 'ability of individuals in power to interact and influence others within an organisation' (Chiu and Lao, 2008, p. 38). This interaction involves leaders and followers in which the former, leads the latter to act in ways that help attain certain goals. Thus, the values and motivations such as wants, needs, aspirations and expectations of both leaders and followers must be recognised (Burns, 1978, p. 8-9; Chee, 1991, p.5). Recognition of the needs and motivations of both leaders and followers is indeed crucial to ensure a good relationship between leaders and followers. Hence, if leaders have good relations with their followers, it is easier to get followers to conform to their decisions (Terada, 2001, p. 201). Taking into consideration leaders and followers as social human beings, Yukl (1994) defined leadership as 'a process where one member of a group influences other members towards attaining specific group goals' (cited in Tang, 2006, p. 70).

Leadership in a regional or international organisation is much more complex than a domestic one. The complexity occurs when one state assumes primary control over others and tries to lead them. The ability of certain countries to lead and the willingness of other countries to accept that leadership depends on numerous factors has been difficult to describe (Anwar, 2006, p.59-60). For example, despite the notion that leadership does require certain inherent qualities to be successful, it is also dependent on certain situational conditions. Specifically, leadership would be successful when it emerges at the right time, at the right place, with the right people and the right approach (Tang, 2006, p.74). Moreover, leadership in regional organisations involves an enormous number of actors, namely a group of career bureaucrats, different national leaders and non-governmental organisations (NGOs) from each regional member country. This complexity explains why there is relatively little in-depth literature that deals with international or regional leadership, especially in the international relations context (Tang, 2006, p.71).

Leadership has been regarded as one of the main factors that promote institution-building and multilateral cooperation in the international system (Hidetaka, 2005, p. 209). Leadership plays an important role in determining an institution's aim, agenda, values, membership and the undertaking of diplomatic efforts to deal with issues involving their organisations (Terada, 2001: 195-220). Young (1991) identified leadership as one of the critical factors that affects any successful international institution, since leadership is a critical determinant of success or failure in the institutional bargaining process at the international stage (Young, 1991, p.281). The measure of an institution's success lies in the success of its institutional bargaining at the international society level.

In other words, leadership is crucial in ensuring the success of regional or international institutions. Tang (2006) defined successful international leadership as the combination of any 
of the following five objectives; preventing conflict (leadership for preventive diplomacy), winning a just war by leading a war coalition among nations, bringing conflict to an end (leadership for ending war), building the foundation of lasting peace (leadership for building peace or reconciliation), and advancing the common interest of a group of states (leadership for common interest) (Tang, 2006, p. 70). This study argues that Malaysia's leadership in ASEAN belongs to the fifth category of successful international leadership: advancing the common interests of a group of states (Tang, 2006, p. 70). Malaysia has been successful in its pursuit to push forward the ASEAN agenda while promoting common interest among the ASEAN member countries to accomplish the goals set by the organisation.

\section{Malaysia's Membership in ASEAN}

Malaysia, formerly known as the Federation of Malaya under the leadership of the late Tunku Abdul Rahman, was not an avid supporter of the idea of establishing ASEAN in 1967. Tunkul had bitter memories of Sukarno's 'konfrontasi' policy and was sceptical of Indonesia's intention and commitment to form a new regional organisation (Phanit, 1980, p. 35). Indonesia, under the leadership of Sukarno's nationalist vision, made the idea of a new Southeast Asian regional organisation almost impossible to materialise. Sukarno opposed the idea of a regional organisation, especially when there was a possibility that the Federation of Malaya would join such an endeavour, as it went against his vision for Indonesia. For Sukarno, the idea of a newly constituted Malaysia was a neo-colonial plot by the British to besiege Indonesia (Antolik, 1990). The President had publicly declared a protest through propaganda called Ganyang Malaysia, or 'Crush Malaysia' campaign, in September 1963. Eventually, this led to the launch of a period known as 'Konfrontasi' or the war between Malaysia and Indonesia that occurred between 1963 - 1966 (Antolik 1990, pp. 18-19).

In addition to being the founder of the Association of Southeast Asia (ASA), Tunku Abdul Rahman was reluctant to see the ASA scrapped for a new regional organisation, specifically if its formation would allow the inclusion of Indonesia (Anwar, 1994, pp. 25-26). However, most members of Malaysia's Foreign Ministry did not fully share Tunku's view and managed to provide strong arguments for closer ties with Indonesia. Strong justifications presented by the Malaysian Foreign Ministry officials, coupled with the persuasiveness of Thanat, the former Thai Foreign Minister, Tunku eventually reassessed his stance and accepted Jakarta's insistence on the need for ASEAN (Phanit, 1980, p. 35). The resistance was later subdued by the reconciliation between Malaysia and Indonesia, and subsequently strengthen the trust between the two states.

On 8 August 1967, five ministers that represented the governments of Indonesia, Malaysia, Singapore, Thailand, and Philippines gathered in Bangkok to discuss the establishment of a new association for Southeast Asian nations. They signed the two-page Bangkok Declaration, the founding document of ASEAN. The Bangkok Declaration detailed the 
driving principles of ASEAN with respect to state sovereignty and non-interference, to which the leaders strongly adhered. Furthermore, it has never been on the agenda of ASEAN leaders to surrender their sovereignty to a regional institution, although efforts to strengthen the institutional and legal frameworks are becoming increasingly apparent since the ratification of the ASEAN Charter in 2007 and the ASEAN Economic Community in 2015.

Over five decades, ASEAN has been coined by scholars as the most successful regional organisation among developing states. The organization has been able to maintain peace and stability within the region, without the eruption of war among its member-states (Nesadurai, 2009; Stubbs, 2008). Moreover, it has provided a unique framework for regional community-building (Beeson, 2009, pp. 21-22; Severino, 2007, p. 406). Malaysia remains a key regional player in Southeast Asia, and has been successful in promoting and maintaining peace in the region

In its first decade, ASEAN was focused on building solidarity among its members through various cooperation agendas (Palmer and Reckford, 1987, p. 7; Severino, 2008, p. 63). In its second decade, the organisation concentrated on conflict management and played a diplomatic role in the resolution of the Indochina conflict (Severino, 2008, p. 63; Morada, 2008, p. 37). In its third decade, it promoted regional economics and security cooperation. In doing so, it widened its membership to include Cambodia, Laos, Myanmar and Vietnam, and extended its diplomatic cooperation into Northeast Asia via the ASEAN Regional Forum (ARF) (Jones and Smith, 2007, p.184). The third decade since its inception, was considered a turning point for ASEAN during the 1997 Asian Financial Crisis that had hit major ASEAN countries (Jetschke and Ruland, 2009, p. 197). The crisis affected economic growth and political stability of ASEAN member countries, especially Indonesia, Malaysia and Thailand. In its fourth decade, it boosted regionalism and community building (Morada, 2008: 27), through the Bali Concord II (2003), with the establishment of the ASEAN Community and ASEAN Charter in 2003 and 2007 respectively. The latter was introduced as an attempt to support and ensure that the ASEAN Community initiative becomes a reality by 2015, the time horizon scheduled during the ASEAN Ninth Summit Meeting in October 2003.

\section{Malaysia's Contribution to ASEAN}

This section presents the analysis of Malaysia's contribution to ASEAN. Through detailed historical analysis, this section is aimed at identifying the extent to which Malaysia's role has been paramount in chartering the development of ASEAN. This includes the area of political-security development, economic policy and social agendas. The analysis comprises the early-years of ASEAN'S establishment until the writing of this article. From the analysis, several agendas and initiatives were identified that have been proposed and implemented by Malaysia, as discussed in the following subsections. 


\section{Political-Security Development}

\section{The Declaration of the Zone of Peace, Freedom and Neutrality (ZOPFAN)}

As the host of the ASEAN Foreign Ministers' meeting held in Kuala Lumpur on 27 November 1971, Malaysia declared that the ASEAN member-states had agreed to establish the Zone of Peace, Freedom and Neutrality (ZOPFAN). The objective of establishing ZOPFAN was to acknowledge 'the right of every state, large or small, to lead its national existence free from outside interference in its internal affairs as this interference will adversely affect its freedom, independence and integrity'. Moreover, the signatories of ZOPFAN agreed to maintain peace, freedom and independence of their countries unperturbed by any of the other member-states.

This idea was the brainchild of the late Tun Dr Ismail Abdul Rahman when he proposed the 'Peace Plan' in 1968. Tun Dr Ismail's 'Peace Plan' was then adopted by the late Tun Abdul Razak, the second Prime Minister of Malaysia, and converted it into a proposal for a Zone of Peace, Freedom and Neutrality. In 1971, Tun Dr Ismail (cited in Abad, 2000, p. 3) noted that, "it is with Vietnam in mind together with the withdrawal of the Americans and British from Southeast Asia that my government is advocating a policy of neutralization for Southeast Asia to be guaranteed by the big powers, viz. the U.S., U.S.S.R., and the People's Republic of China'. Furthermore, he claimed that 'the policy is meant to be a proclamation that this region of ours is no longer to be regarded as an area divided into spheres of influence by the big powers. It might be regarded as a project to end or prevent small countries in this region from being used as pawns in the conflict between the big powers. The policy of neutralization represents a programme that ensures stability and preserves peace in this region so that we might get on with the urgent task of developing our countries and improving the wealth and welfare of our peoples' (Tun Dr Ismail, 1971, cited in Abad, 2000, p.3).

Malaysia's proposal received a lukewarm response from other member-states. Singapore, which preferred (and still does) an economically oriented regional organisation, acknowledged the proposal. The then Singapore Foreign Minister, S. Rajaratnam stated in 1972 that "my Government believes that ASEAN should remain an organization for economic cooperation. However, ASEAN countries cannot isolate their economic strivings from the political issue of war and peace that big power politics will and are introducing into the region' (cited in Abad, 2000, p. 2). Likewise, Indonesia's response was not as encouraging either. Adam Malik, the former Foreign Minister of Indonesia asserted that 'the nations of Southeast Asia should consciously work towards the day when the security of their own region will be the primary responsibility of Southeast Asian Nations themselves' (cited in Far Eastern Economic Review, 1971, pp. 31). However, both Thailand and the Philippines were sceptical, considering their close bilateral relation with the United States. Despite the negativity, Malaysia was adamant in proceeding with the proposal and utilised the Foreign Minister's Meeting on 27 November 1971 held in Kuala Lumpur, to officially declare ZOPFAN. 
Nonetheless, this accomplishment provided the basis of ASEAN's stance on regional and world affairs. It recognised the principle of a nuclear weapons-free zone and the neutralisation of Southeast Asia as a desirable objective (Solidum, 2003, p.103). Specifically, under ZOPFAN, the ASEAN countries agreed to respect the sovereignty and territorial integrity, and avoid activities that threatens the security of the region. They agreed to exclude foreign powers, especially the United States, U.S.S.R and People's Republic of China from interfering with ASEAN countries and prevent them from using the region as a theatre for conflict (Palmer and Reckford, 1987, p. 12).

\section{Advancing the expansion of ASEAN}

Since the establishment of ASEAN, the founding members had envisioned that ultimately, ASEAN would be comprised of the ten Southeast Asian nations. In the early days of ASEAN, only five countries were willing to join the organization; Malaysia, Indonesia, Thailand, Singapore and Philippines. Subsequently, Brunei joined the five-founding countries of ASEAN in 1984. Vietnam's admission in 1995 made it the first communist country in the region to join ASEAN and gave final closure to the political turmoil between communist and non-communist states in Southeast Asia. It was decided at the 1995 ASEAN Summit in Cebu, Philippines, that the actualization of the ASEAN-10 should be achieved by the year 2000, with the admission of Cambodia, Laos and Myanmar.

Under the leadership of Mahathir Mohamad, Malaysia was keen to admit the three potential member countries at the ASEAN Ministerial Meeting (AMM) in 1997, three years earlier than initially anticipated. This was reflected in Mahathir Mohamad's statement in 1997 that 'the ASEAN Ten should become a reality quickly, not slowly' (ASEAN Secretariat 1997). Mahathir Mohamad believed that ASEAN would continue to be a formidable regional organisation if Cambodia, Myanmar and Laos joined ASEAN. Mahathir (1997) envisaged that the political and economic benefits that the ASEAN Ten could offer was 'important in determining ASEAN's own destiny, as well as to influence the pace and direction of Asia Pacific affairs' (ASEAN Secretariat 1997). According to Mahathir Mohamad, the three new member countries would increase the total population of ASEAN by 600 million people and would be an advantage for ASEAN, especially in regional market and economic developments.

It was Mahathir's insistence and perseverance to vehemently counter those who criticised him, that expedited the process for admission of the three least-developed countries in the region. Mahathir was adamant to make the ASEAN-10 a reality, despite international criticism from ASEAN's two important dialogue and trading partners, the United States and European Union, due to the Myanmar junta's atrocious human rights record (Weatherbee, 2010). Laos and Myanmar eventually joined ASEAN in July 1997 while Cambodia's admission was deferred due to the country's internal political struggle, but ultimately joined ASEAN on 30 April 1999. 


\section{Malaysia and the Road to the ASEAN Charter}

Based on document analysis, Malaysia has indeed played a key role in progressively advancing the establishment of the ASEAN Charter, which is a document that confers the legal personality of ASEAN. In 2005, the ten leaders of the ASEAN member countries agreed on the need to formally establish an ASEAN Charter at the $11^{\text {th }}$ ASEAN Summit meeting in Kuala Lumpur. However, Malaysia had been urging the other member-states in ASEAN to support the introduction of a Charter since 2000. In 2000, Malaysia published a paper entitled Review of ASEAN's Institutional Framework: Proposal for Change (ASEAN Secretariat, 2004). Malaysia's proposal received positive feedback from the other memberstates, through a statement by the Foreign Ministers of ASEAN member states, "we agreed towards the development of the ASEAN Charter, and we express appreciation to Malaysia for its paper, 'Review of ASEAN Institutional Framework: Proposal for Change' (ASEAN Secretariat, 2004).

Former Prime Minister of Malaysia, Tun Abdullah Badawi (2004) expressed his thoughts on the ASEAN Charter at the National Colloquium on ASEAN, which was held in UiTM Shah Alam, Malaysia on 7 August 2004 when he said that 'the time may also be ripe now to begin thinking about an ASEAN Charter. This need not be an overly ambitious project. Instead, it should be a practical document designed to streamline and strengthen ASEAN's processes, mechanisms and working methods. It should incorporate all of ASEAN's basic documents. Such a Charter will confer upon ASEAN an international legal personality. It will provide the legal framework for incorporating ASEAN decisions, treaties and conventions into the respective national legislations of member countries' (ASEAN Secretariat, 2004).

Malaysia exploited its 2005 ASEAN Chairpersonship to hasten the progress of establishing the ASEAN Charter. Therefore, by reflecting on the role of Malaysia in dictating foreign policy, the then ASEAN Secretary General, Ong Keng Yong (2011), during an interview with the author, mentioned that 'we [ASEAN] agreed on the idea of the ASEAN Charter. This is surely a very big matter. But Malaysia has officials at every level to propagate this idea, to draft the Charter. This is the way to do it, this is the way to talk about it'. For instance, Malaysia insisted on the establishment of the Eminent Persons Group (EPG). The role assumed by the ASEAN's eminent persons group was to gather recommendations and provide guidelines for the creation of a Charter. The draft of the Charter was completed in October 2007. It was in the following year when the Charter eventually came into effect, on 15 December 2008. Since then, it has been the backbone of ASEAN's documentation, mechanisms and working methods.

\section{Economic Development}

\section{East-Asia Economic Caucus}

In terms of economic development, Malaysia advocated the idea of establishing the East Asia Economic Group (EAEG) in 1990. EAEG is a forum established to discuss and 
conduct dialogue about economic issues, which comprises ASEAN members as well as China, Japan and South Korea. Mahathir Mohamad introduced the notion of East Asia, integrating Northeast and Southeast Asia into one regional unit (Terada, 2003, p. 256). The objectives of EAEG are to boost economic cooperation, to promote and defend free trade, accelerate economic growth, introduce open regionalisms, and contribute to multilateral trading systems.

The decision to propose the EAEG was due to the emergence of economic blocs and treaties around the globe, such as the EU and NAFTA, which challenged and competed with the economic growth of Southeast Asia nations. Mahathir believed that for ASEAN to have a bigger bargaining power during international trade negotiations, they must work together with other East Asian countries (Severino, 2006, p. 265). However, with the U.S denouncing the formation of the EAEG and Japan's decision to not join the proposed association due to its loyalty to the U.S, and while the other ASEAN members were not consulted, the idea was shelved. It took a considerable time before the ASEAN members finally considered it.

Mahathir's proposal received a lukewarm response from other ASEAN members, especially Indonesia. Indonesia was concerned of the lack of previous intra-ASEAN consultations, while others were suspicious of the anti-Western tone of the proposal. Nonetheless, with Mahathir's initiative coupled with the need to ensure subsequent discussions, the concept was watered down to the East Asia Economic Caucus. In December 1997, Malaysia hosted an informal ASEAN summit and invited the leaders of China, Japan and South Korea to meet with the ASEAN leaders for a general forum to strengthen diplomatic ties. Since then, East Asian leaders have been included in the meetings with ASEAN members during the annual ASEAN Summit. Essentially, the forum became known as ASEAN+3, emphasising the centrality of ASEAN's role, the character of the forum as a process rather than as an institution and its nature of openness (Severino, 2008, p.266).

Mahathir returned to domestic and international politics as the $7^{\text {th }}$ Prime Minster of Malaysia in June 2018. It is expected that his presence would nurture internal unity within ASEAN, considering his experience and achievements in gaining international recognition for both Malaysia and ASEAN. Thus, when Mahathir came to power, the revival of EAEC began to occur. During a speech at the Nikkei Conference at Tokyo in June 2018, Mahathir discussed the role of the EAEC and insisted that it should be joined by other Central Asian countries, such as India (The Star 2018).

\section{Socio-Cultural Development}

\section{ASEAN Humanitarian Aid Missions}

Malaysia has played a major role in ASEAN humanitarian aid missions, both financially and through human resource efforts. These include providing assistance to countries affected by 
natural disasters such as Indonesia (Aceh and Jogjakarta), Myanmar, Laos, Cambodia and Philippines as well as becoming an intermediary for peace talks between the Philippines government and MILF (Moro Islamic Liberation Front) (Bernama 2017). Moreover, Malaysia has shown tremendous commitment and willingness to focus on offering and providing humanitarian aid for the Rohingya people since the conflict between Myanmar and the Rakhine state escalated in recent years.

Malaysia has been regarded as the most vocal country in criticising and commenting on the issues surrounding the Myanmar-Rohingya crisis and plays a critical role in facilitating humanitarian assistance, both on its own and jointly with other ASEAN countries (Parameswaran, 2018; Yee, 2017). The Malaysian government and its leaders have been vocal, and is expected to continue to speak out against Myanmar on the Rohingya issue (Mohamed Pero \& Ismail, 2017, p. 119). Malaysia's involvement in the crisis intensified under the leadership of the $6^{\text {th }}$ Prime Minister of Malaysia, Najib Razak. It is expected that the current Prime Minister, Mahathir Mohamad, would continue to voice out his distaste on the Rohingya crisis. In a recent statement in November 2018, Mahathir slammed Myanmar's leader, Aung San Suu Kyi, for her stance in trying to 'defend the indefensible' in an attempt to vindicate violence by Myanmar against the Rohingyas (Reuters 2018). The leaders' and the viewpoint taken by Najib's and Mahathir's government on the Myanmar issue is a reflection of the demands and wishes of the majority of Malaysians. In September 2017, the Prime Minister's Office issued a statement stating that 'it is hoped that this mission [humanitarian aid mission] will carry the wishes of all Malaysians and the spirit of 'Negaraku Prihatin' (My Concerned Country,) based on the right-to-security demanded by every human being (Bernama, 2017).

Malaysia, along with Thailand and Indonesia, is the largest host country for refugees in Southeast Asia, despite the fact that Malaysia is not a signatory to the 1951 Refugee Convention (European Commission, 2018). UNHCR Malaysia reported that, at end of November 2018, there were almost 163,600 refugees and asylum-seekers registered with the UNHCR in Malaysia, whereby 141,700 were from Myanmar (81,760 Rohingyas, 27,130 Chins, 9,800 Myanmar Muslims, 4,010 Rakhine, Arakan and other ethnicities) (UNHCR Malaysia, 2018).

In addition, Malaysia has advocated the rights and plight of the Rohingya at the international stage, through the United Nations and the Organisation of Islamic Cooperation. During a speech at the $72^{\text {nd }}$ Session of the United Nations General Assembly (72 ${ }^{\text {nd }}$ UNGA) in September 2017, the then Foreign Minister of Malaysia, Anifah Aman demanded Aung San Suu Kyi to end atrocities committed against the Rohingya community. Anifah Aman stated that "clearance operations" of Rohingya ethnics by Myanmar have claimed the lives of countless innocent civilians and caused more than 400,000 Rohingya to be displaced from their homes (Yunus 2017). He added that, "such atrocities have unleashed a full-scale humanitarian crisis that the world simply cannot ignore but must be compelled to act upon" (quoted in Yunus 2017). 
Moreover, Malaysia has disassociated itself from the statement issued by the Philippine Foreign Secretary and the current ASEAN Chairperson, Peter Cayetono, regarding the Rohingya issue. Certainly, this was a rare and bold step taken by an ASEAN member-state, considering the organization's cardinal principle of non-interference and 'ASEAN Way' code of ethical practice. The ASEAN Chairman's statement issued at the side-lines of the United Nations General Assembly in New York on the 23 September 2017, 'expressed concern over the recent developments in Northern Rakhine State in Myanmar' following the August 25 violence, where 77 Rohingya Muslims and 12 security forces were killed. Malaysia's Foreign Minister, Anifah Aman, labelled the statement as a 'misrepresentation of reality', on the basis that the statement omitted the fact that 'the Rohingya are one of the affected communities' (Mohamed Pero \& Ismail, 2017, p. 119).

Malaysia has been immensely involved in its humanitarian support for Myanmar, regardless of the change in government in May 2018. In October 2017, Najib Razak launched the third "My Country's Concerned Humanitarian Mission for Rohingya", which provided 56.6 tonnes of food and essential items for refugees occupying the Myanmar-Bangladesh border (Malay Mail, 2017). By the end of 2017, it was reported that Malaysia had transported 2,300 tonnes of aid in the form of clothing, food items and emergency supplies to Myanmar. Furthermore, Malaysia has built 323 shelter homes, 22 schools, 127 clean water bases and distributed 22,455 packets of food to the Rohingya civilians by November 2017 (Muslimin, 2017).

Malaysia's relentless efforts to help the Rohingyas, led to the construction of a field hospital in Ukhia, Bangladesh, called Medan Malaysia Hospital (HMM) (Parameswaran 2018). Malaysia is the first country to establish a fully functional and complete field hospital in the area that is comparable to some specialist hospitals in Malaysia, with a maximum capacity of 100 beds and staffed by trained doctors and medical personnel. The construction and operation of the hospital was a result of concerted efforts by various Malaysian agencies that includes the Ministry of Health, National Security Council, Foreign Ministry and the Malaysian Armed Forces. Since the the start of its operation on 3 December 2017 until February 2018, the field hospital has managed to provide treatment to 6,578 patients, conducted 218 surgeries and delivered 31 babies (The Star 2018).

The decision to operate the field hospital, which was initially planned under the leadership of Najib Razak, was made at the end of 2018 (The Star 2018). The current government under Prime Minister Mahathir Mohamad, has decided to extend the services of the Malaysian medical field staff to cater for the needs of the Rohingya refugees. According to Foreign Minister Datuk Saifuddin Abdullah, this decision was in line with Pakatan Harapan's policy to help the Rohingya civilians who are being oppressed (Sarawak Voice 2018). In addition to help ease the operations of the field hospital, Malaysia has been able to garner support from other countries. Saudi Arabia, United Arab Emirates and Brunei have helped provide medicines, vehicles and ambulances, as well as equipment such as pumps and water filters 
for the hospital (Bernama 2018). The United Kingdom and Australian governments have also shown their interests and commitment to help with the operation of the hospital by dispatching medical teams and staff (Bernama 2018).

\section{Conclusion}

Based on the arguments and examples presented in this study, Malaysia can be deemed as a leader within ASEAN, championing several important policies at the international arena. Malaysia has demonstrated considerable political will and commitment to advocate economic and social policies, and thus have the capacity to act upon its stated policies and agenda. The study has demonstrated the political will of the Malaysian leaders to recognise, identify and promote the benefits of regional initiatives. For the advancement and success of ASEAN and the country, Malaysian leaders have acted courageously and displayed sheer determination to tackle the risks to achieve their stated objectives and perceived benefits accruing from the cooperation between member-states.

From the analysis conducted in the study, there is a correlation between state capacity and leadership function in the ASEAN context. In particular, this study demonstrated that the state's capacity has been crucial for playing leadership roles in ASEAN in order to maintain the benefits of regional community-building through agenda-setting and continued policy implementation. In the ASEAN context, the state's capacity is a significant factor in the prioritisation of a certain member-state's agenda, in its effort to advance the progress of ASEAN.

This study has found that the personality of political leaders is another crucial factor. The personality can either act as a driver or an impediment to regional community-building. This is evident in the case of Mahathir Mohamad, who promoted and advanced numerous ASEAN initiatives and agendas especially on the issues of its membership and expansion, particularly with the attainment of the ASEAN-10. The ppersonality and political will of Malaysian leaders have been influential in policy prioritisation and the exclusion of certain agendas, therefore affecting the overall progress and direction of the ASEAN communitybuilding.

The findings from the study have raised several questions that are worth further examination. For example, the theoretical and empirical foundation can be studied and analysed to define leadership in regional organisations. A reflection of Malaysia's experience in providing leadership to ASEAN indicates that, although Malaysia has shown unwavering commitment in advancing the progress of ASEAN, Malaysia has yet to be considered as a leader within the organisation. Hence, future studies should focus on other facades of leadership such as followership, to understand the nexus between leadership and regional organisation. 


\section{References}

Antolik, M. (1990). ASEAN and the diplomacy of accommodation. New York \& London; An East Gate Book.

Anwar, D. F. (1997). ASEAN and Indonesia: Some reflections. Asian Journal of Political Science, 5, 20-34.

ASEAN Secretariat (2004). Address of His Excellency Dato' Seri Abdullah Bin Haji Ahmad Badawi, The Prime Minister of Malaysia "Towards An ASEAN Community" at The National Colloquium on ASEAN, 7 August. Retrieved from https://asean. org/?static_post=address-of-his-excellency-dato-seri-abdullah-bin-haji-ahmadbadawi-the-prime-minister-of-malaysia-towards-an-asean-community-at-thenational-colloquium-on-asean.

ASEAN Secretariat. (1997). Opening Statement his excellency Dato' Seri Dr. Mahathir Bin Mohamad Prime Minister of Malaysia. Retrieved from http://www.asean.org/news/ item/opening-statement-his-excellency-dato-seri-dr-mahathir-bin-mohamad-primeminister-of-malaysia>.

ASEAN Secretariat. (2004). Joint communique of the thirty-seventh ASEAN ministerial meeting Jakarta. Retrieved from http://www.asean.org/news/item/joint-communiqueof-the-37th-asean-ministerial-meeting-jakarta-29-30-june-2004-2 2 .

Beeson, M. (2009). ASEAN's ways: Still fit for purpose. Cambridge Review of International Affairs, 22(3), 333-343.

Bernama. (2017). Malaysia to send humanitarian mission to aid Rohingya refugees. Retrieved from https://www.malaysiakini.com/news/394559.

Bernama (2018). Mindef wants Cox's bazar field hospital to be kept open for another year. Retrieved from https://www.malaysiakini.com/news/440777.

Burns, J. M. (1978). Leadership. New York; Harper \& Row.

Chee, S. (1991). Introduction. In S Chee (Eds.), Leadership and security in Southeast Asia: institutional aspects. Singapore: Institute of Southeast Asian Studies (ISEAS), 1-12.

Emmers, R. (2014). Indonesia's role in ASEAN: A case of incomplete and sectorial leadership. The Pacific Review, 27(4), 543-562.

Eisenhardt, K. M. (1989). Building theories from case study research, The Academy of Management Review, 14(4), 532-50.

European Commission. (2018). European civil protection and humanitarian aid operations Thailand, Malaysia, and Indonesia. Facts and Figures. Retrieved from https:// ec.europa.eu/echo/where/asia-and-pacific/thailand_en.

Hidetaka, Y. (2005). Political leadership, informality, and regional integration in East Asia: The evolution of ASEAN plus three. European Journal of East Asian Studies, 4(2), 205-232.

Jetschke, A., \& Ruland, J. (2009). Decoupling rhetoric and practice: The cultural limits of ASEAN Cooperation. The Pacific Review, 22(2), 179-203.

Jones, D. M., \& Smith, M. L. (2007). Making process, not progress: ASEAN and the Evolving East Asian Regional Order. International Security, 32(1), 148-184. 
Klenke, K. (2008). Qualitative research in the study of leadership. Emerald Group Publishing Limited Bingley.

Koh, T. (2008). ASEAN at Forty: Perception and reality. Singapore: Institute of Southeast Asian Studies.

Malay Mail (2017). Najib launches third humanitarian mission for Rohingya. Retrieved from https://www.malaymail.com/s/1492737/najib-launches-third-humanitarian-missionfor-rohingya.

Mohamed Pero, S. D., \& Ismail, N. (2017). Regional organisations and crisis management: ASEAN and GCC's approaches to Rohingya crisis. Journal of Law, Government and Communication, 2(6), 114- 126.

Morada, N. M. (2008). ASEAN at 40: Prospects for community building in Southeast Asia. Asia-Pacific Review, 15(1), 36-55.

Muslimin, A. (2017). ASEAN's Rohingya response - Barely a peep outside Malaysia. Forbes. Retrieved from https://www.forbes.com/sites/anismuslimin/2017/12/17/ aseans-rohingya-response-barely-a-peep-outside-of-malaysia/\#4b200f9139de.

Nesadurai, H. (2009). ASEAN and regional governance after the Cold War: from regional order to regional community? The Pacific Review, 22(1), 91-118.

Nesadurai, H. E. (2008). The Association of Southeast Asian Nations (ASEAN). New Political Economy, 13(2), 225-239.

Palmer, R. D., \& Reckford, T. J. (1987). Building ASEAN: 20 Years of Southeast Asian Cooperation. New York: Praeger Publisher.

Phanit, T. (1980). Regional integration attempts in Southeast Asia: A study of ASEAN's problems and progress. England: University Microfilms International.

Rattanasevee, P. (2014). Leadership in ASEAN: The role of Indonesia reconsidered. Asian Journal of Political Science, 22(2), 113-127.

Reuters (2018). Defending the indefensible: Malaysia's Mahathir slams Suu Kyi over Rohingya crisis. Retrieved from https:/www.reuters.com/article/us-asean-summitmalaysia-myanmar/defending-the-indefensible-malaysias-mahathir-slams-suu-kyiover-rohingya-crisis-idUSKCN1NI12W.

Sarawak Voice (2018). Cox's Bazar field hospital services to be continued. Retrieved from https://sarawakvoice.com/2018/10/31/coxs-bazar-field-hospital-services-to-becontinued/.

Severino, C. R. (2006). Southeast Asia in search of an ASEAN Community: Insights from the former ASEAN Secretary-General, Singapore; Institute of Southeast Asian Studies.

Severino, R. (2007). ASEAN beyond forty: Towards political and economic integration. Contemporary Southeast Asia, 29(3), 406-423.

Severino, R. (2008). ASEAN at Forty: A balance sheet. Southeast Asian Affairs, 61-70.

Solidum, E. D. (2003). The politics of ASEAN: An Introduction to Southeast Asian Regionalism. Singapore: Eastern Universities Press.

Stubbs. (2008). The ASEAN alternative? Idea, institutions and the challenge to 'global' governance. The Pacific Review, 21(4), 451-468. 
Tang, S. (2006). Leadership in institution building: The case of ASEAN+3, In Fort, B. \& Webber, D. (Eds.), Regional integration in East Asia and Europe: Covergence or divergence. London; Routledge.

Terada, T. (200). Directional leadership in institution-building: Japan's approaches to ASEAN in the establishment. The Pacific Review, 14(2), 195-220.

Terada, T. (2003). Constructing an 'East Asian' concept and growing regional identity: From EAEC to ASEAN+3. The Pacific Review, 16(2), 251-277.

The Star. (2018). Malaysia not against TPPA, but favours EAEC. Retrieved from https:// www.thestar.com.my/news/nation/2018/06/11/malaysia-not-against-tppa-butfavours-eaec/

UNHCR Malaysia (2018). Figures at glance in Malaysia. Retrieved from https://www. unhcr.org/figures-at-a-glance-in-malaysia.html.

Weatherbee, D. (2010). International relations in Southeast Asia: The struggle for autonomy. Institute of Southeast Asian Studies (ISEAS), Singapore.

Yee, T. H. (2017, Sept 7). Myanmar crisis: Humanitarian effort by ASEAN a possibility. The Straits Times. Retrieved from https://www.straitstimes.com/asia/se-asia/ humanitarian-effort-by-asean-a-possibility

Young, O. (1991). Political leadership and regime formation: on the development of institutions in international society. International Organization, 45(3), 281-307.

Yukl, G. (1994). Leadership in organizations. New Jersey: Prentice Hall. 